\title{
O REPÚdio DAS MULHERES PELO MARIDO NO DIREITO MUÇULMANO, VISTO PELO SUPREMO TRIBUNAL FEDERAL
}

\author{
NEGI CALIXTO*
}

\begin{abstract}
SUMÁRIO
1. O Instituto do Repúdio. 2. O Repúdio na família Islâmica. 3. Extraterritorialidade da sentença. 4. Homologação de sentença estrangeira. 5. Jurisprudência do Supremo Tribunal Federal. 6. Conclusão.
\end{abstract}

1. Instituto que enseja particular meditação, é o Repúdio figura extravagante admitido nos mais variados reinos conservadores ou reacionários, nos mais destacados Estados progressistas ou radicais, que sofre determinadas condições, em uma gama extraordinária de fórmulas prazos deveres, mas, sempre, sob severas restrições.

Rotulando o casamento em quaisquer de suas concepções - a clássica, também chamada idividualista, que reconhece como contrato por acordo entre os cônjuges (RADBRUCH, Filosofia do Direito, 2/67); a supra-individualista que percebe-o como uma grande instituição social (SALVAP. Tratado de Derecho Civil Argentino, 11/12); e a eclética que ROUAST chamou-o de de ato complexo, ao mesmo tempo contrato e instituição (Apud - WASHINGTON DE BARROS MONTEIRO, Curso, 1957, Saraiva) tem no Repúdio uma das causas de seu rompimento, conhecido no direito romano, ao lado do divórcio por mútuo consentimento (bona gratia), como repudium - divórcio pela vontade vontade de um só cônjuge.

A sua preponderância está nos países muçulmanos contemporâneos tanto nos Estados conhecidos como progressistas,

* Professor Assistente de Direito Internacional Privado na Universidade Federal do Paraná. 
âradicais ou esquerdistas (Turquia, Egito, Irã, Iraque, Paquistão)., como nos conservadores ou reacionários (Arábia Saudita, lemen. Jordânia, Afganistão, Marrocos, Kuwait, Oman e reinos do Golfo), correspondendo, de modo geral, aos dois sistemas de divórcio neles vigentes: o grupo conservador mantendo o tradicional Repúdio unilateral a favor do marido, juntamente com a poligamia, e os progressistas adotando o divórcio ocidental, com igualdade de direitos para os cônjuges, e ao mesmo tempo, abolindo, em certos países, e em outros limitando, a poligamia.

Há ainda alguns sistemas híbridos, nos quais se adota o divórcio à ocidental, mas com certo favorecimento ao marido, com manifestação de Repúdio (compromisso entre o tradicional regime patriarcalista e a crescente ocidentalização) - (Apud ALíPIO SILVEIRA. O divórcio vincular, S.P. 1972).

2. A instituição do Repúdio das mulheres pelo marido, em aliança com a poligamia, é mais acentuada no Alcorão, Código religioso, moral e civil dos muçulmanos.

Som a palavra ALíPIO SILVEIRA para o enfoque da família muçulmana e a instituição do Repúdio:

"A Constituição da família muçulmana é muito diferente daquela da família cristã: é mais indefinida, envolvente e complicada. O casamento não tem nela a mesma força cogente, as cerimônias são muito menos solenes - na verdade, mal pode dizer-se que exista uma celebração pública. Um primeiro casamento não impede o homem de contrair nova união sendo a poligamia inteiramente legal. E, além do estado marital, o esposo pode coabitar com um número ilimitado de escravas. O estatuto dos filhos destas concubinas é todavia, idêntico ao dos filhos das muheres legítimas, de modo que o próprio casamento não é elemento indispensável à legitimidade dos filhos. Além disso, o casamento muçulmano é precário: o divórcio é mais facilmente obtido do que em qualquer seita protestante. A bem dizer, não é realmente o divórcio que o Islam admite - é o direito do marido ao repúdio, o qual pode ser exercido de modo quase absoluto. Os costumes muçulmanos não dão ao casamento a mesma importância social que the conferimos: a esposa, sempre reclu- 
sa em seus aposentos, ou coberta com o céu, não aparece absolutamente na sociedade. O convidado ou o hóspede nunca devem falar a um muçulmano sobre suas mulheres ou mesmo pedir-lhe notícias delas.

Maomé proibida a massa de seus adeptos, de ter mais de quatro esposas legítimas. A tradição fixou este limite de quatro esposas aos crentes comuns, e autorizou os Califas e Sultões, como sucessores do Proefta, a terem nove. Os muçulmanos, como já dissemos, segundo a tradição prevalente, podem ter as escravas que quiserem; estas escravas são frequentemente postas aos serviços de suas muIheres legítimas. e outro lado, um elevado número de esposas é um dos luxos quase obrigatório para um personagem de alta posição. A idéia da inferioridade da mulheres é das que dominam todo o sistema da vida e família mulçulmana". (obr. cit.)

Exsurge, portanto, a preponderância do homem, patriarcalista por excelência, na família islâmica.

De conseqüência é o Repúdio o elemento primeiro para a dissolução do casamento, como vontade unilateral.

Salientado por RENÉ DAVID (in Os Grandes Sistemas do Direito Contemâorâneo. Meridiano, Lisboa, 2. ${ }^{a}$ ed.) como o fundamento do direito muçulmano, como de toda a civilização muçulmana, o Alcorão ou Corão (gorão) constituiu o conjunto de revelações de Alá ao último dos seus profetas e mensageiros, Mafoma ou Mohamad, destacando como primeira fonte desse direito sem ser, necessariamente, um código.

Dessas fontes (Alcorão e a Suna) os doutores do Islão determinam as regras da châ'ia (heresia) devendo o direito muçulmano ser olhado inteiramente independente de todos os outros sistemas de direito, que não têm as mesmas fontes.

Observe-se, no entanto, como RENÉ DAVID, que "a vida social não comporta, para um muçulmano, outras regras que não sejam as da sua religião, de que o direito muçulmano constitui uma parte integrante" (obr. cit. p. 480), mas concide, hoje, com a evolução desse mesmo direito, porque "o direito muçulmano comporta muito poucas disposições imperativas e deixa uma grande amplitude à iniciativa e à liberdade humanas. É também 
possível para aqueles que querem, sem serem infiéis ao Islão, modernizar as regras de vida na sociedade, utilizar o processo da convenção" (obr. cit. p. 484).

Razão por que a jurisprudência admitiu que os esposos possam, ao casarem-se, estipular legitimamente que a mulher poderá repudiah-se, ela própria, exercendo uma prerrogativa de seu marido, ou que teria esta faculdade se o marido cotninuasse a ser monógamo, etc.

Há, portanto, uma tendência desencorajante das práticas do repúdio unilateral e preponderante do marido.

3. A nossa mais Alta Corte de justiça tem sido chamado, por inúmeras vezes, a conhecer esse instituto no fenômeno da por inúmeras vezes, a conhecer esse instituto no fenômeno da extraterritorialidade da sentença, no campo do Direito Processual Internacional.

É princípio geral do Direito que a decisão judicial tem eficácia limitada à jurisdição onde foi proferida.

Para o orum, as sentenças festrangeiras não passam de fatos relevantes; sem dúvida, são atos oiciais de fjurisdição autônomas, mas destituídos de obrigatoriedade. Por isso "nenhum Estado pode pretender que os julgados de seus tribunais tenham per se força executória, ou valor processoal em jurisdição estranha" (AMILCAR DE CASTRO "in" Direito Internacional Privado, Forense, 19773, mas observando-se a doutrina da equivalente jurisdicional (MORELLI, CARNELUTTI, GOODRICH), entendeu-se que não havia ofensa à soberania nacional em admitir-se alguém a mover no forum, com base em sentença estrangeira, não nova ação de conhecimento, mas uma actio iudicati (LA LOGGIA), preponderanto em quase todos os países, com raras exceções, a execução dessas sentenças, ou por meio de outra ação de conhecimento, ou mediante o processo meio de outra ação de conhecimento, ou mediante o processo de delibação ou deexequatur, precisamente, como assinala AMILCAR DE CASTRO, porque a sentença é ato público, praticado legitimamente em jurisdição estranha, e que no forum não se lhe pode sistematicamente negar valor.

É a atribuição, no forum, de validade a atos judiciais emanados de países estrangeiros.

SERPA LOPES ministrou certa feita que "lei e sentença, em geral, são ordens, comandos. Onde há ordem e comando, há im- 
pério e jurisdição, e império e jurisdição implicam soberania e limites territoriais a essa mesma soberania" e, com a evolução, essa mesma ordem e comando repercute além fronteira, daí o surgimento da execução da sentença em jurisdição estranha.

A homololagação de sentença estrangeira ou deliberação da sentença, limita-se, no sistema brasileiro, a verificação do cumprimento de certos requisitos essenciais, sem examinar-lhe o mérito.

Homologar é tornar o ato, que se examina, semelhante, adequado, ao ato que devia (PONTES DE MIRANDA), por isso na delibação, o modelo que se tem em vista é a sentença de igual conteúdo que porventura fosse proferida pela Justiça brasileira, cujo objeto é a sentença proferida por tribunal estrangeiro.

4. O direito processual civil internacional ao consagrar o princípio da execução extraterritorial da sentença deu lugar a vários sistemas legislativos que disciplinam o instituto da homologação; sistema da revisão do mérito da sentença (Dinamarca e Holanda); sistema da revisão do mérito, no caso da decisão estrangeira ter feito aplicação da lei nacional; sistema da reciprocidade diplomática; sistema da reciprocidade de fato.

O sistema que, cientificamente, se chama de delibação, surgido na Itália, em 1865, no Código de Processo Civil Italiano, e que melhor corresponde à conveniência dos Estados e dos postulantes, é o adotado pelo Brasil.

Duas vantagens apontam-no como melhor sistema: respeita-se o pronunciamento judicial da soberania estrangeira e atende-se ao interesse do Estado onde a sentença será executada.

Não há exame do mérito da sentença, exigindo-se, por seus elementos extrínsecos, que ela seja exeqüível e que, por seu conteúdo, não seja contrária aos interesses nacionais, equiparando às decisões judiciais estrangeiras para fins de homologação, as proferidas por órgãos estranhos ao Poder Judiciário, mas no execício de função judicante (ex. divórcio decretado pelo Rei da Dinamarca, por autoridade administrativa norueguesa, ou registrado perante prefeito, no Japão) .

Sendo o processo de homologação da sentença estrangeira de natureza jurisdicional, entende-se que quem requer a homologação propõe verdadeira ação, isto ', para obter título exeqüendo, o portador da sentença deve propor outra ação, fundado 
em seu direito à condenação, com os requisitos exigidos pela lei brasileira (arts. 483 e 484 d Código de Processo Civil 244, mais Súmulas 381 e 420 .

5. Ao Supremo Tribunal Federal, portanto, competem, pelo seu Presidente, o conhecimento e o julgamento das homologações de sentenças proferidas em jurisdições estrangeiras, para surtir efeitos no mundo jurídico brasileiro.

Em pesquisa junto à Corte Suprema verificamos que o instituto do Repúdio, do direito muçulmano, é sempre tratado com reservas, tanto no campo jurídico, como no campo mral de sua aplicação.

Repúdio significa, na língua árabe, TALAK que quer dizer - separação.

LUOIS MILLIOT, professor da Faculdade de Direito de Paris, estudioso do direito mulçulmano, salienta:

"Le mot arabe talak, qui corresponde au mot français "répudiation", désigne, en réalité, divers modes de dissolution du mariage:

- d'abord la répudiation propremente dite, dissolution pronincée par déclaration unilatérale du mari;

- ensuite la dissolution résultant d'un accord entre les conjoints, c'est-à-dire le divorce par consentement mutlel;

- enfin la dissolution résultant d'un jugement, prononcé par le magistrat, d'office ou à la requête de l'un des époux, gé n éral e m e nte la femme, c'est-à-dire le divorce judiciaire" (Introduction a L'Étude du Droit Musulm, Recueil Sirey, Paris, 1953; ainda P. JOSÉ LÓPEZ ORTIZ, in Derecho Musulmán, Labor, 1932, Barcelona).

A esse instituto a egrégia Corte Suprema do Brasil tem dispensado um tratamento especial, como salientamos, bastando ver a jurisprudência aqui selecionada.

$\mathrm{Na}$ Sentença Estrangeira n. 1.914, do Líbano, que contém um trabalho magnífico sobre a natureza jurídica do instituto do Repúdio, pelo professor HAROLDO VALLADÃO, Procurador Ge- 
ral da República, à época, o Supremo Tribunal indeferiu a homologação por falta da citação da mulher, eis que o processo e a sentença foram realizados e proerfidos sem a ciência da mulher, o que a torna, em face de nossa lei, inexeqüível no Brasil. ${ }^{1}$

Vê-se que a egrégia Corte, apesar do parecer favorável do Procurador Geral da República, fez observar a forma prescrita na ordem pública interna brasileira quanto ao direito de ser citada (art. 15 da Introdução ao Código Civil).

Na Sentença Estrangeira n. 2.373, da República Árabe Unida, a Corte brasileira indeferiu a homologação por incompetência da autoridade processante face a desvinculação daquela autoridade do domicílio das partes e, ainda, de suas nacionalidades. $^{2}$

Verifica-se que a negativa da homologação deu-se em razão dos requerentes serem residentes e domiciliados no Brasil, e um deles, brasileiro naturalizado. Predominou, no entanto, o elemento de conexão quanto ao domicílio face ao art. $7 .^{\circ}$ da Lei de Introdução ao Código Civil.

Já, na Sentença Estrangeira n. 2.574-4, do Reino Hashemita da Jordânia, o presidente da Corte Suprema, usando, agora, de sua competência privativa, indeferiu a homologação, não reconhecer o Repúdio como idêntico a qualquer instituto brasileiro. ${ }^{3}$

A decisão salientou que o ato unilateral do Repúdio é inconciliável com o sistema brasileiro de divórcio, que não dispensa, em nenhuma hipótese, a audiência da mulher no processo $\mathrm{em}$ que é ele julgado.

Por fim, a Sentença Estrangeira n. 2.416-1, do Paquistão, em que a Côrte brasileira achou por bem em deferí-la, por obediência todos os requisitos exigidos em nosso sistema de homologação. ${ }^{4}$

6. À vista de tudo que se pesquisou junto ao Tribunal pátrio, concluimos que o juiz nacional procura, por todos os ângulos, dar predomínio à obediência de formalidadés essenciais para o reconhecimento das decisões judiciais estrangeiras, máxime aquelas que acolhem o instituto do Repúdio, examinado a sua forma e o seu conteúdo para salvaguarda de interesse concernentes à ordem pública brasileira. 
(1) SENTENÇA EStRANGEIRA N.`1.914 - LíBANO

RELATOR: O Sr. MINISTRO TEMÍSTOCLES CAVALCANTI. Requerente: MOHAMAD HUSSEIN OMAR SAADEDDINI.

EMENTA - Repúdio entre cônjuges muçulmanos. Reservas da lei brasileira quanto à exigência da citação do cônjuge. Garantia também quanto aos alimentos. Nega-se a homologação.

\section{ACóRDÃO}

Vistos, relatados e discutidos os autos acima identificados, acordam os Ministros do Supremo Tribunal Federal, em Sessão Plenária, na conformidade da ata do julgamento e das notas taquigráficas, por unanimidade de votos, negar a homologação.

BRASÍLIA, 13 de dezembro de 1967. - LUIZ GALLOTTI, Presidente. THEMISTOCLES CAVALCANTI, Relator.

\section{RELATÓRIO}

O SR. MINISTRO THEMISTOCLES CAVALCANTI - MOHADMAD EUSSEIN OMAR SAADEDDINE que também se assina MOHAMAD HUSSEIN SAADEDDINE, libanês, residente no Paraná, pede ao Egrégio Tribunal a homologação da sentença proferida pelo Tribunal "Chari" de Becá, República Libanesa, que decretou a dissolução do seu casamento com Rifaieh Ali Muhamad Al-Ráj Ahmad El-Xádiri, também libanesa.

Juntou a sentença de divórcio decretada à revelia da mulher ausente da audiência, e sem efeito o contrato de casamento que só se poderão novamente reunir mediante novo contrato de casamento. Esta sentença foi dada em 28 de dezembro de 1963.

Foi ordenada a citação da mulher à fl. 16 e cumprida à fl. 22 .

Nomeado curador o advogado DÉCIO MIRANDA, fez exigências à fls. 26 que foram em parte satisfeitas, salvo a relativa à exigência de que a mulher fora citada para o divórcio.

A mulher do requerente não se manifestou nos autos, nem atendeu à sua citação feita. 
Ouvido, o Dr. Curador opinou contra o deferimento porque, embora a questão se deva reger pelo direito muçulmano, a verdade é que os cônjuges se acham domiciliados no Brasil, o que levaria a verificar se a mulher sujeitou-se volutariamente à jurisdição do divórcio no seu país de origem e o cabimento da aplicação do artigo $7 .^{\circ}$ da Introdução do Código Civil, quanto à aplicação da lei do domicílio.

Além do mais, a) a mulher não foi citada para a ação; b) não há prova de submissão da mulher à submissão da mulher à jurisdição estrangeira, com aplicação de uma lei mais severa, como o simples repúdio; c) a ausência de cláusula de pensão alimentícia à mulher domiciliada no Brasil que ficaria praticamente sem meios de subsistência.

Ouvida a douta Procuradoria-Geral, opinou em largo e erudito parecer o Professor Haroldo Valladão favoravelmente ao deferimento do pedido, do qual destaco os seguintes tópicos:

"III. Circunscreve-se a dúvida, no caso, à ofensa à ordem pública que representaria o reconhecimento de um divórcio, decretado no Líbano, para libaneses, do rito muçulmano, sem citação prévia da mulher, reconhecido pelo respectivo tribunal através da antiga regra do repúdio, pela simples vontade do marido. Se o direito brasileiro admite o reconhecimento de um divórcio decretado, sem fraude, em um Estado, segundo suas leis, por seus tribunais, para seus nacionais, é, e'm princípio, indiferente apurar se o divórcio ali litigioso e por que causas, se por mútuo consentimento e em que forma e condições, ou se, qual na espécie, pela simples vontade de um dos cônjuges.

A forma antiqüíssima do abandono pelo marido, o senhor, da mulher, a escrava, e, também, por esta, com o repúdio de um ou de outro (Droit Musulmain, L. Milliot, Paris, 1953 p. 348 n..$^{\circ}$ 454; Derecho Matrimonial Islamico, PP. Garcia Bariuso, Madrid n.'s 371 e 11) foi atenuada pela Bíblia (Deuteronômio, 124,1) ao exigir para o repúdio ter o marido encontrado na mulher "algo torpe", e escrever-lhe o libelo ( a carta de repúdio, salvo duas exceçoes em que o repúdio é proibido (Deuteronômio, XXII, 13 e 19;28/9), pois escrever exige tempo, reflexão, procura de um es- 
criba, submeter-se às exigências deste; ademais era mister proceder à entrega pessoal da carta, etc. Admitia-se em casos excepcionais que a mulher exigisse do marido o repúdio (Derecho Hebreo, Mateo Goldstein, Buenos Aires, 1938 pp. 277/282).

No direito muçulmano o repúdio, talak, excepcional, como a "coisa lícita", "mais odiosa" (Derecho Musulman), J. Lopes Ortiz, Barcelona, 1952, p. 165; Derecho Musulman, Manuel de Nilo $\mathrm{Y}$ Torres, Tetuan, 1927, p. 78; Averroes, Bidaya, Du Mariage et sa Dissolution, Alger, 1926, p. 156; Direito Muçulmano, Juyboll, Milano, 1916, p. 146/7; Trité de Droit Musulmain, Houdas et Martel, Alger, 1882, p. 259, n. 389; Droit Comparé, Arminjon Nolde, Wolff, 3, n. 1.018, etc) - é admitido pelos vários ritos, sob determinadas restrições, - e condições perante 0 respectivo juiz, Cadi, que o decreta, segundo se vê da sentença ora em causa, fl. 3, com diversas fórmulas, prazos, deveres - (Ops. cits).

O repúdio pode ser declarado, quer pelo marido, até sem apresentar motivo, quer pela mulher, com motivos previstos (Langlard, Leçons de Droit Musulmain, Pondcherv, 1887, n. ${ }^{\circ}$ S 116/7/8; Houdas e Martel, cit. p. 263; La Bidaya, cit. 180/1; Lehr, Le Mariage et le Divorce, 1.899, p. 311, e, especialmente, Droit Musulmain, L. Milliot, $n .{ }^{\circ}$ 354). A mulher tem direito à restituição do dote, a uma pensão alimentar no prazo de quatro meses, Iddeh, imprescindível para a validade do repúdio (tempo de reconciliação), e the cabe, ainda, a guarda dos filhos, até 7 anos e das filhas até 9 anos; em certos ritos se the reconhece direito a uma indenização (La Bidaya, dit. p. 243). Tem direito a pedir divórcio, chul'o (Lehr, cit.), por certas causas.

IV - Evidentemente no direito muçulmano a mulher ainda se acha em condição inferior ao homem em matéria de dissolução de casamento.

Note-se, porém, que a mulher libanesa, muçulmana, aceitou o divórcio pelo repúdio, declarado pelo marido perante o tribunal muçulmano de Beirute e sabe ela bem dos seus interesses, Milliot, op. cit. n. ${ }^{\circ} 357$, escreveu: "envisagés du point de vue de l'interet de 
la femme, la répudiation e la signification d'une restauration de sa liberté, principe toujours enccuragé par le droit musulmain".

A citação se fez após a declaração do repúdio, após a decretação do divórcio (Ops. cits. e doc. de fl. 39). Decretado a 28-12-1962, fl. 4, fine, foi feita a respectiva citação, fl. 29, a 28-3-1974, e só após tal citação tornou-se o divórcio definitivo, depois "que a Rifaiech foi notificada na forma da lei", segundo se acentua na certidão do Tribunal, fl. 7 , fine, e $7 \mathrm{v}$., princípio.

Essa citação feita por intermédio do Consulado libanês não ofende a ordem pública, segundo tem admitido o Supremo Tribunal Federal, e mostra que a esposa não quis protestar ou recorrer na Justiça de seus países.

Aqui, também, a esposa foi citada, neste autos, fl. 22 , e nada reclamou, sequer quanto a alimentos.

$\mathrm{V}$ - No reconhecimento de ato e sentença de outro Estado a ordem pública incide, apenas, nos efeitos que irão produzir no Brasil.

Ora. a dissolução do casamento desses dois libaneses pedida expressamente pelo marido, e aceita pela mulher sem reclamação, terá como efeito permitir a eles novo casamento, qual se permite em todos os inúmeros outros casos de divórcio decretado em outro Estado para seus nacionais, divórcios sempre homologados pelos Supremo Tribunal Federal. Se o direito brasileiro, nesses casos, acha que o divórcio no estrangeiro não ofende a ordem pública, não há como proclamar, genericamente, que tal espécie de divórcio, lá permitida, seja a ela contrário".

Menciona direito comparado e termina:

VIII - Em face do exposto não nos parece ocorrer, no caso, ofensa à ordem pública, na homologação de sentença do Líbano, de divórcio por repúdio, ali decretado por tribunal muçulmano para libaneses muçulmanos domiciliados no Brasil, tendo sido a mulher citada, na forma processual muçulmana após a decretação, sem nada opor, deixando ocorrer o trânsito em 
julgado, e nada reclamando, depois de citada no Brasil, nestes autos da respectiva homologação. Nem houve a fraude à lei, por exemplo, dos divórcios de certos Estados do México.

IX - Opinamos, assim, na forma da jurisprudência, pela homologação para todos os efeitos, do divórcio decretado pela decisão de fl. 3 do Tribunal "Chari" (muçulmano sunita) de Beca no Líbano".

\section{vото}

O SR. MINISTRO THEMISTOCLES CAVALCANTI - (Relator) - Não obstante o parecer favorável do douto ProcuradorGeral da República, Professor Haroldo Valladão, não homologo a sentença, pelas seguintes razões.

O divórcio ou repúdio foi requerido por procurador quando ambos os cônjuges já residiam no Brasil e a mulher só teve conhecimento da ação depois de decretado o divórcio. A sentença é de 28 de dezembro de 1963 e dela só teve a mulher conhecimento em 28 de março de 1964, no Paraná.

Ora, a introdução do nosso Código Civil, art. 15, exige para a execução no Brasil de sentença estrangeira:

h) - terem sido as partes citadas ou haver-se legalmente verificado a revelia.

A própria tradução da sentença é datada de 6 de março de 1964.

Foi, portanto, o processo e a sentença realizado e proferido sem a ciência da mulher, o que a torna, em face de nossa lei, inexeqüível no Brasil.

Silencia também em relação aos bens e alimentos, com transgressão da nossa lei civil que manda aplicar a lei brasileira para regular as relações a eles concorrentes - (Art. 8. da Introdução).

É bem verdade que o repúdio é uma instituição protegida pela lei do país de origem dos cônjuges e é bem possível que o divórcio represente para a mulher uma libertação do jugo do marido, jugo que talvez não se exerça com o mesmo rigor em nossas terras quanto em seu país de origem, mas não é menos certo que a lei brasileira só reconhece esses regimes quando não ofendam a ordem pública e os bons costumes. 
Nego a homologação por falta absoluta de citação da muIher e por ausência de cláusula alimentícia que atenda às necessidades mínimas de susistência.

É, segundo me parece, a proteção a ser prestada pela lei brasileira aos estrangeiros aqui domiciliados, na execução das sentenças estrangeiras que colidem com os costumes da terra.

\section{VOTO}

O SR. MINISTRO VICTOR NUNES LEAL - Estou de acordo com o eminente Ministro Themístocles Cavalcanti. Tenho certa dúvida quanto ao problema dos alimentos, mas basta o outro fundamento. No meu voto, este problema fica em aberto, pois já temos homologado sentenças de divórcio em que não há cláusula de alimentos.

\section{EXTRATO DA ATA}

SE 1.914 - Líbano - Rel. Min. Themistocles Cavalcanti. Reqte. Mohamad Hussein Omar Saadeddine, que também assina Mohamad Hussein Saadeddine (Adv. Maurício P. da Rocha). Negou-se a homologação, unânimemente. Plenário, em 13.12.67.

Presidência do Sr. Ministro Luiz Gallotti. Presentes os Senhores Ministros Moacyr Amaral Santos, Themístocles Cavalcanti, Raphael de Barros Monteiro, Eloy da Rocha, Oswaldo Trigueiro, Evandro Lins, Hermes Lima e Victor Nunes Leal. Licenciado o Sr. Ministro Lafayette de Andrada, Ausentes, justificadamente, os Srs. Ministros Adaucto Cardoso, Prado Kelly, Djaci Falcão, Adalício Nogueira e Gonçalves de Oliveira. Dr. Álvaro Ferreira dos Santos, Vice-Diretor-Geral. (in Supremo Tribunal Federal, Sentenças Estrangeiras, 1979, pgs. 411/416).

\section{(2) SENTENÇA ESTRANGEIRA}

\section{N.⒉373 (AGRG) - REPÚBLICA ÁRABE UNIDA}

Relator: O Sr. Min. THOMPSON FLORES

Agravantes: KAMAL ABDEL RAHMAN GENENA E POLIXENE MARIE COCORIS WITTEVEEN.

EMENTA: Divórcio procedido perante a Embaixada da República Árabe Unida (Egito), no Brasil. 
Decretação por manifestação unilateral do marido. Afronta à ordem pública.

II. Incompetência da autoridade processante, desvinculada tanto do domicílio quanto da nacionalidade das partes.

III. Pedido de homologação indeferido. Agravo regimental não provido.

\section{ACÓRDÃO}

Vistos, relatados e discutidos estes autos, acordam os Ministros do Supremo Tribunal Federal, em sessão plenária, na conformidade da ata do julgamento e das notas taquigráficas, por unanimidade de votos, negar provimento ao agravo.

Brasília, DF., 10 de novembro de 1977. - Carlos Thompson Flores, Presidente e Relator.

\section{RELATÓRIO}

O SR. MINISTRO CARLOS THOMPSON FLORES: - Neguei homologação ao divórcio dos requerentes, nestes termos, fls. 28/34:

"Vistos.

KAMAL ABDEL RAHMAN, GENENA, de nacionalidade brasileira, e POLIXENE MARIE COCORIS WITTEVEEN, holandesa, ambos residente na cidade de São Paulo, requerem a homologação de seu divórcio "declarado pela Embaixada da República Árabe Unida (Egito) na cidade do Rio de Janeiro."

2. Com o pedido além das procurações de fls. 4 e 5 oferecem os documentos de fls. 6/17.

3. Distribuídos os autos emitiu parecer contrário a douta Procuradoria-Geral da República, nestes termos, fls. 21/4:

“1. Kamal Abdel Rahman Genena, de nacionalidade brasileira e Polixene Marie Cocoris Witteveen, de nacionalidade holandesa, requerem, representados por um mesmo procurador, a homologação 
“... do divórcio declarado pela Embaixada da República Árabe Unida (Egito), na cidade do Rio de Janeiro, e registrado sob o número 58 , em 16 de novembro de 1970, no Cartório Central do Registro Civil do Cairo" (fl. 2).

2. Prevenindo, desde logo, todo equívoco em torno das razões que levarão esta Procuradoria Geral a opinar pelo indeferimento do pedido, cumpre desenvolver dois raciocínios preliminares.

De início, nada há de inédito na decretação do divórcio por autoridade desvinculada do Poder Judiciário. Nos países escandinavos, bem como no Japão, defere a lei a órgãos do Poder Executivo competência para atos que, entre nós, incumbem à Justiça, mais por cautela do legislador, atento a determinadas conveniências, que por autêntica consideração da natureza de tais atos. Configuram eles a chamada jurisdição voluntária, cuja essência não é inerente à função judicante dos magistrados, jamais havendo faltado à melhor doutrina pátria a necessária clarividência para entender razoável que, alhures, semelhantes espécies se sordinem à autoridade administrativa. Nessa trilha, decisões homologatórias do divórcio por mútuo consentimento, proferidas por órgãos do Executivo, na Dinamarca, na Noruega e no Japão, têm merecido a chancela do Supremo Tribunal brasileiro (v., inter alia, SE 1943, R.T.J., 43/641, e SE 2.251, D.J. de 27-2-76, p. 1.281).

Em segundo lugar, não haveria por que recusar à pretensa sentença em exame a qualidade de estrangeira, à base do fato de haver sido lavrada no Rio de Janeiro. Nada autoriza a vislumbrar nesse evento um reflexo do regime das capitulações, outrora adotado por potências coloniais em território asiático ou africano. Como todo Estado soberano, tem o Egito a prerrogativa de facultar a seus juízes que administrem justiça em alto mar ou em território estrangeiro. Respeitada a ordem interna, e patenteada 
a inteira ineficácia da sentença fora do âmbito territorial da soberania que a endossa, não terá havido heresia em sua prolação, não menos legítima que o exercício ordinário das funções consulares.

3. Sucede que não nos encontramos, na espécie, em face de um divórcio por consentimento mútuo, mas de uma dissolução do matrimônio pela vontade unilateral do marido, de que o agente diplomático egípcio se limitou a lavrar termo. A certidão de fl. 7 evidencia que o requerente compareceu à Embaixada, identificouse, e, na presença de testemunhas,

“... declarou que os laços matrimoniais entre ele e sua esposa acima mencionada existem, bem como a convivência matrimonial entre eles, e que ele divorcia sua esposa acima mencionada, acrescentando: "Minha esposa Polixene Jean Cocoris é divorciada de mim".

Ao cabo desse exótico procedimento, não amigável, visto que unipessoal, e muito menos contencioso, por idêntica razão limitou-se o agente diplomático a declarar:

"Assim sendo, ela é divorciada dele..." etc. A esposa marcou, não há negar, sua discreta presença. Chegou mesmo a ser ouvida sobre a guarda da filha menor e sobre contribuições pecuniárias. Tudo isso, porém, depois de consumada a dissolução do matrimônio. Não cabe especular em torno de um possível assentimento tácito, de uma íntima vontade da muIher, voltada para aquele desfecho. Nem há que argumentar à base de seu ulterior casamento com súdito holandês, ou de sua atual qualidade de co-requerente da homologação. A tese inequívoco divórcio por manifestação unilateral de vontade se opõe a ordem pública brasileira, em cujo nome a pretensão homologatória há de desmerecer amparo.

4. Posto em pauta e dela retirado, vieram os autos conclusos por força do despacho de fl. 26 , 
com base na Emenda Constitucional n. ${ }^{\circ} 7 / 77 \mathrm{e}$ Emenda Regimental n. $4 / 77$.

5. Quando nada do que foi exposto tivesse procedência, ou seja, caso nos encontrássemos em face de autêntico divórcio por mútuo consentimento, ou de sentença resultante do contencioso regular, ainda assim descaberia a homologação, e desta feita por incompetência do juío, ou de qualquer autoridade egípcia, para decretar o divórcio. Sabe-se, ad nauseam, que nessa matéria não cumpre admitir a legitimidade do foro eleito. O domicílio e a nacionalidade das partes, alternativamente, devem justificar a competência. No caso, os cônjuges eram ambos domiciliados no Brasil. A mulher conservava sua nacionalidade grega originária. O marido, por naturalização, era brasileiro desde 1968 (fl. 12). Nenhum préstimo tem, nessas circunstâncias, sua nacionalidade egípcia anterior, ainda que, para a lei egípcia, ele a conservasse a despeito da naturalização, como faz crer a peça de fl. 7. Isto porque não se nos opõe a chamada "dupla nacionalidade", devendo todo brasileiro ser havido estritamente como tal.

Por último, o lugar da celebração do matrimônio não configura fator determinante da competência para o divórcio, sendo exclusivo, nesse terreno, o binômio domicílio-nacionalidade, à base do qual tem essa Corte tantas vezes convalidado a dissolução, por divórcio absoluto, de casamentos celebrados no Brasil.

6. Pelo indeferimento da homologação, por imperativo de ordem pública, e, subsidiariamente, face à incompetência internacional da autoridade egípcia.

Brasília, 10 de novembro de 1976.

José Francisco Rezek,

Procurador da República.

Aprovo: HENRIQUE FONSECA DE ARAÚJO,

Procurador Geral da República. 
4. Posto em pauta e dela retirado, vieram os autos conclusos por força do despacho de fl. 26, com base na Emenda Constitucional n. $7 / 77$ e Emenda Regimental n. $4 / 77$.

II. Isto posto, indefiro o pedido. Faço-o adotando como razões de decidir as do parecer transcrito.

Publique-se.

Brasília, 17 de maio de 1977".

2. Publicadas suas conclusões no D.J. de (26) vinte e seis de maio último, a (3) três do corrente, inconformados, interpuseram os peticionários 0 presente agravo regimental.

Sustentam que a forma de divórcio é admitida pelo Direito Muçulmano e pelo Código Civil do Egito; que a mulher aceitou a dissolução da sociedade conjugal e, ademais, que competente era a autoridade egípcia, pois, pela lei do Egito, onde se realizaram as núpcias, é o requerente daquela nacionalidade, embora se haja naturalizado brasileiro desde 1968.

Pleiteiam, assim, a pretendida homologação de divórcio.

3. Mantive o veredicto agravado, e, na forma regimental, trago o feito a julgamento.

É o relatório.

O SR. MINISTRO CARLOS THOMPSON FLORES (Relator). Nego provimento ao agravo.

2. Os agravantes não trouxeram com a petição de recurso de fls. 36/8 qualquer argumento novo que estivesse a exigir outras considerações.

3. Todavia, para melhor esclarecer o Tribunal, procedo desde já à leitura do instrumento de divórcio que se encontra à fl. 7 (lê).

4. Verifica-se, de logo, que razão assiste ao parecer adotado, quando afirma que a dissolução se deu pela vontade unilateral do marido.

É conhecida esta forma de divórcio perante o Direito Muçulmano, o "Tolok", referido pelos tratadistas (Milliot, Int. a L'Étude du Droit Musulman, pp. 347 e seguintes). 
Conquanto válido e eficaz no país onde se realizaram as núpcias, eis que ali se operou o registro, teria reservas em emprestar-lhe efeitos entre nós face ao disposto no art. 17 da L.I.C.C.

Este Plenário negou homologação à sentença de divórcio proferida por autoridade judiciária do Líbano fundada em repúdio manifestado pelo marido. $\mathrm{E}$ isto porque a mulher não fora citada. Refiro-me à SE n. ${ }^{\circ} 1.914$ e da qual fora relator o eminente Ministro Temístocles Cavalcanti (RTJ 44/357).

5. Inobstante, fundamento proeminente, per se arrebataria a possibilidade da homologação.

É que os requerentes são desidentes e domiciliados no Brasil, como confessam, e, ademais, um deles naturalizou-se brasileiro em 1968, nacionalidade que conserva.

Ainda que estrangeiros fossem, seu estatuto pessoal passaria a ser o do domicílio em questão, Brasil, pelo qual se regem, entre direitos outros, os de família, nos quais se compreende o divórcio.

É o que decorre do disposto no caput do art. $7 .^{\circ}$ in fine, da L.I.C.C.

Quando não se aceitasse a questão de fundo, pelo menos, seria manifestamente incompetente, para gerar efeitos no Brasil, a autoridade que recebeu a manifestação de vontade para reconhecer o divórcio, o que, per se, obstaria a homologação, como dispõe o art. 15, a, da citada Lei de Introdução (R.I., art. 212 II).

Esta é, ademais, a lição dos autores (Espínola Filho, Lei de Introdução ao Código Civil Comentada, II, 330, 336/9 e 351; Amilcar de Castro, Direito Internacional Privado, Forense, 1977, pp. 369 e seguintes).

Nestes princípios se inspiraram a Súmula n. ${ }^{\circ} 381$, e os julgados que a têm aplicado (SE n. ${ }^{\circ}$ 2.082, Bolívia, Pleno, 30-11-72, in R.T.J., 64, pp. 24/36).

É o meu voto.

\section{EXTRATO DA ATA}

SE 2.373 - (AgRg) - República Árabe Unida - Rel., Min. Thompson Flores. Reqtes.: Kamal Abdel Rahman Genena e Polixene Marie Cocoris Witteveen (Advs.: Ricardo Farah e Fernando Bonfim Filho). 
Decisão: Pediu vista o Min. Cunha Peixoto, após o voto do Relator negando provimento ao Agravo Regimental. - Tribunal Pleno, 17 de junho de 1977.

Presidência do Sr. Ministro Carlos Thompson Flores. Presentes à sessão os srs. Ministros Djaci Falcão, Bilac Pinto, Antonio Neder, Xavier de Albuquerque, Rodrigues Alckmin, Leitão de Abreu, Cordeiro Guerra, Moreira Alves e Cunha Peixoto. - Procurador-Geral da República, o Prof. Henrique Fonseca de Araújo.

Dr. Alberto Veronese Aguiar, Secretário do Tribunal Pleno.

\section{VOTO VISTA}

O SR. MINISTRO CUNHA PEIXOTO - Kamal Abdel Rahman Genena, de nacionalidade brasileira, e Polixene Marie Cocoris Witteveen, de nacionalidade holandesa, requerem, representados pelo mesmo advogado, a homologação.

“... do divórcio declarado pela Embaixada da República Árabe Unida (Egito), na cidade do Rio de Janeiro, e registrado sob o número 58, em 16 de novembro de 1970, no Cartório Central do Registro Civil do Cairo".

O eminente Ministro Thompson Flores indefiriu o pedido de homologação da sentença.

Posto admitida a homologação do divórcio decretada por autoridade desvinculada do Poder Judiciário, como ocorre nos países escandinavos, árabes e no Japão, tenho, como o eminente Ministro-Relator, não pode ser a atual sentença homologada. Não pelo fato de ter sido decretado o divórcio no Consulado, nem pelo fato de ter ocorrido por vontade unilateral, do marido, já que a mulher participou do ato e foi ele realizado de conformidade com as leis que regem o instituto no Egito. Como ensina Haroldo Valladão.

“... a homologação inclui todas as sentenças estrangeiras de divórcio, sentenças no sentido material, embora pronunciadas por órgãos não judiciários; administrativos, legislativos, etc. (veja-se homologação de divórcios decretados pelo Rei da Dinamarca, o Governador de uma província da Noruega e o Prefeito de uma cidade do Japão, por consentimento mútuo,..." (Direito Internacional Privado, vol. II, p. 126).

Acontece, porém, que os requerentes são domiciliados no 
Brasil e um deles, antes do divórcio, naturalizou-se brasileiro, nacionalidade que conserva.

Ora, o Brasil não admite a dupla nacionalidade, e se aqui não se admite o divórcio para o brasileiro, evidente que não o poderia permitir também para aquele que se tornou brasileiro por naturalização.

Por estes motivos, também nego provimento ao agrado regimental.

\section{EXTRATO DA ATA}

SE. 2.373 - (AgRg) - República Árabe Unida - Rel., Min. Thompson Flores, Reqtes.: Kamal Abdel Rahman Genena e Polixene Marie Cocoris Witteveen (Advs. Ricardo Farah e Fernando Bonfim Filho).

Decisão: Negado provimento, unânimemente - T. Pleno, 10 de novembro de 1977.

Presidência do Sr. Ministro Thompsom Flores. Presentes a sessão os Srs. Ministros Djaci Falcão, Bilac Pinto, Antonio Neder, Xavier de Albuquerque, Rodrigues Alckmin, Leitão de Abreu, Cunha Peixoto e Soares Munñoz - Ausentes, justificadamente, os Srs. Ministros Cordeiro Guerra e Moreira Alves.

Procurador-Geral da República, o Prof. Henrique Fonseca de Araújo.

Dr. ALBERTO VERONESE AGUIAR, Secretário do Triunal Pleno. (in Supremo Tribunal Federal, Sentenças Estrangeiras, 1979. pgs. 633/639).

\section{(3) SENTENCYA ESTRANGEIRA}

SE 2.574-4 - REINO HASHEMITA DA JORDÂNIA.

AUTOR: - MUHAMMAD ABDER RAHMAN ABDALLA KHALIL (Advs.- Hugo Mósca e outros).

RÉ: FATMETH ABDALIA DIB ABDALIA OU FATMETH ABDALLA DIB ABDLLA BAYOUD.

EMENTA: 1. Sentença proferida pelo Tribunal Religioso, de Amã, Reino Hashemita da Jordânia, pela qual foi aprovado ou ratificado 0 ato de repúdio da mulher postulado pelo marido no Centro Islâmico do 
Brasil, situado em São Paulo. Caso em que o varão e a mulher são jordanianos domiciliados neste nosso País.

2. O repúdio da mulher concretizado pelo marido, e permitido pelo Direito Muçulmano, é um ato que não merece definido como divórcio, visto que, por suas peculiaridades, não se harmoniza com esse instituto vigorante no Brasil, quer formal, quer materialmente.

3. Ação homologatória de sentença jordaniana de divórcio julgada improcedente.

\section{SENTENÇA}

Vistos e analizados estes autos de Ação Homologatória de Sentença Estrangeira n. 2.574-4, em que é autor Muhammad Abder Rahman Abdalia Khalil e ré Fatmeth Abdalla Dib Abdalla, etc.

II. Muhammad Abder Rahman Abdalia Khalil, jordaniano, domiciliado no Brasil (Manta Maria, RS), requer seja homologada, para que tenha eficácia neste nosiso País, a sentença traduzida na f. 12 e a traduzida na f. 76 , sentenças que ele define como de divórcio proferidas pelo eg. Tribunal Religioso de Amã, Reino Hashemita da Jordânia, para ratificar o ato a que chama de divórcio e que teria dissolvido o seu casamento com Fatmeth Abdalia Dib Abdalla, jordaniana, domiciliada no Brasil (Santa Maria, RS), ato esse processado no Centro Islâmico do Brasil, situado em São Paulo, f. 13.

A Ré foi pessoalmente citada para responder a este homologatória, fl. 55 v., mas ficou na revelia, f. 58 .

Oficiando no caso, a eg. Procuradoria-Geral da República emitiu este parecer, f. 79:

“1. O teor dos presentes autos, e, em especial, o que se registra às fls. 13, conduz à firme suposição de que a espécie retrate um divórcio para manifestação unilateral de vontade. A ser este o quadro real, e a preservar-se a trilha da jurisprudência dessa alta Corte, prece-me inexistente toda perspectiva de sucesso para o pedido de homologação. Não se estendendo além do caso mais recente, permite-se o Ministério Público invocar a SE 2.373, de 1977, em que a figura do repúdio foi amplamente analisada. 
2. Como quer que seja, padecem ainda os autos da falta de parte expressiva daquilo que, nos termos do Regimento Interno, reclamou o Ministério Público no parecer preliminar de fls. 62. Assim, queda indemonstrada a citação regular da mulher para o processo de divórcio, e falta ainda a chancela consular aos documentos originários do foro jordaniano.

3. A hipótese parece ser a de indeferimento do pedido inicial, a menos que esta augusta Presidência haja por bem conceder novo prazo ao requerente, para que regularize a instrução do feito".

III. Feito assim o reltório do essencial constante deste caso, passo à fundamentação desta sentença.

Pelo que se lê nos documentos de fls. 12, 13, 72, 76 e 86, o Autor na verdade repudiou a sua mulher, com a qual se casou no Reino Hshemita da Jordânia, e o fez com apoio no Direito muçulmano imperante naquele Reino, repúdio esse a que chamou divórcio.

Trta-se de ato unilateral permitido pelo Direito jordaniano, mas inconciliável com o sistema brasileiro de divórcio, que não dispensa, em nenhuma hipótese, a audiência da mulher no processo em que é ele julgado.

Pelo que dispõem os artigos 15 e 17 da L.I.C.C.B. e os artigos 216 e 217 do Regimento Interno do Supremo Tribunal, deve notar-se que o reconhecimento de sentença estrangeira pressupõe afinidade entre o ordenamento jurídico do Estado que haja proferido tal sentença e o do Estado a que se tenha pedido a sua homologação.

Com efeito, é indispensável que os dois ordenamentos jurídicos, o do Estado que profere a sentença e o do Estado que a recebe para homologação, hajam pelo menosinstituído um órgão jurisdicional que observe um procedimento em que algo haja de comum aos dois, porquanto, do contrário, não tem sentido falar-se em competência, na citação ou revelia, em firmeza da sentença, nas formalidades indispensáveis à sua execução, nem tampouco na preservação da ordem pública, dos bons costumes e d soberania nacionl, como se lê nos artigos 15 e 17 da L.I.C.C.B. e nos artigos 216 e 217 do Regimento Interno do Supremo Tribunal Federal.

É observação de Redenti (Derecho Procesal Civil, Trad. esp. de Melendo e Redin, Buenos Aires, III p. 87). 
Ora, o repúdio permitido no Direito muçulmano é ato unilateral do varão, ato que não tem correspondência no Direito brasileiro, que pressupõe, no divórcio postulado pelo marido, a citação da mulher no caso de procedimento judicial, ou a sua concordância no caso de procedimento amigável.

No repúdio é bastante a vontade manifestada pelo marido, qual sucedeu na espécie, em que o Autor, ele somente, postulou o reconhecimento da rejeição, que foi aprovada ou ratificada, pelo Tribunal Religioso da Amã, Reino Hashemita da Jordânia, pela sentença ora discutida.

Vê-se que um tal procedimento não se harmonia com a ordem pública brasileira, e que, por isto, não pode merecer homologação entre nós a sentença que se originou dele.

Basta considerar que não foi citada a mulher para 0 procedimento de que resultou a questionada sentença, e que a citação, no Direito brasileiro, constitui requisito de homogabilidade, como expressa o art. 15, b) da L.I.C.C.B.

Doutro lado, tal sentença não apresenta a indispensável autenticação consular, nem registra sua firmeza.

E completa, pois, a incompatibilidade formal e material do referido ato com o Direito brasileiro, sobre o divórcio e a homologação da sentença brasileira.

Registro que a SE n. 2.373 versou o mesmo tema, e que este Plenário, julgando a espécie por meio de agravo regimental, confirmou o julgado negatório da homologação proferido pelo então Presidente Thompson Flores (conf. Supremo Tribunal Federal, Sentenças Estrangeiras, 1979, págs. 633 a 639).

IV. Pelos fundamentos expostos, julgo improcedente a homologatória e condeno o Autor a pagar as custas.

Supremo Tribunal Federal, 5 de novembro de 1980. Min. Antonio Neder, Presidente. (D.J.D. 11.281, pág. 679).

\section{(4) SENTENÇA ESTRANGEIRA N $.^{\circ} 2.416-1$ - PAQUISTÃO}

Requerente: - Humayum Mirza

Requerida: - Shahnaz Mirza.

EMENTA - Divórcio. Cônjuges estrangeiros. Legislação muçulmana. Repúdio perante Juiz Civil. Homologação deferida. 


\section{VISTOS}

Humayum Mirza, cidadão de nacionalidade paquistanesa, residente e domiciliado em Washington, EUA, requer a homologação da sentença de 21 de fevereiro de 1973, proferida pelo Juiz de Direito da Corte Municipal de Karachi - Paquistão, que decretou seu divórcio de sua concidadã Shahnaz Mirza, por isso que pretende contrair casamento com brasileira aqui residente, fl. 2.

Instruiu seu pedido com os documentos de fls. 3 a 25 .

2. Feita a citação-edital, e não comparecendo ao feito a requerida, oficiou o Dr. Curador Especial designado, nos seguintes termos, fls. $46 / 49$ :

"O advogado infra-assinado, nomeado Curador à lide, vem, nos autos da Sentença Estrangeira n. ${ }^{\circ}$ 2.416, expor e afinal dizer a V. Ex. ${ }^{a}$ o seguinte:

Trata-se de pedido de homologação de sentença proferida pelo Juiz de Direito da Corte Municipal de Karachi - Paquistão, que decretou o divórcio e dissolveu o casamento do requerente e seu cônjuge Shahnaz Mirza, ambos cidadãos paquistaneses.

Antes do exame do pedido, propriamente dito, necessárias se tornam algumas considerações sobre a presente sentença de divórcio, visto tratar-se de repúdio ou "talak".

No "Manuale di Diritto Mussulmano", de TH. W. Juynboll, o "talak" ou "Telak", é assim definido:

"Il talak é il ripudio della moglie pronunziato dal marito. Già molto tempo prima di Maometto il talak era generalmente in uso presso gli Arabi e significava per essi l'immediato e definitivo scioglimento del matrimônio. Esso aveva uma certa simiglianza com la manomissone degli schiavi: il marito rununziava mediante il talak a tutti i suouri diritti sulla Moglie. per quanto era possibile le consequenze di rippuddi avventati Maometto concesse al marito la facoltá di rigigliare come moglie la donna respinta, dentro um certo tempo. Durante questo perito di riflessione (lddah) dopo il talak si poteva stabilire anche se la donna fosse incinta". (Aut. cit. Obra citada pág. 145). 
No repúdio, nosso vocábulo correspondente ao árabe "talak", o casamento é dissolvido pela própria vontade do marido, sendo um ato jurídico que torna ilegítimas as relações entre os cônjuges, e que proíbe ao marido quaisquer relações com a mulher, até que ela se case novamente. (O. Houdas e F. Martel, "Traité de Droit Mussulman" (pág. 259 e verso).

Nos países mulçulmanos, islâmicos, o casamento se dissolve pelo repúdio, sentença judicial ou apostasia, sendo o repúdio o sistema mais característico.

Haroldo Valladão, em parecer exarado nos Autos da Sentença Estrangeira n. ${ }^{\circ} 1.914$, do Líbano, teve oportunidade, quando Procurador-Geral da República, de emitir parecer favorável à sua homologação, por entender que o divórcio, decorrente do repúdio, não opendia à ordem pública, do qual se destaca o seguinte trecho:

"Se o direito brasileiro admite o reconhecimento de um divórcio decretado, sem fraude, em um Estado segundo suas leis, por seus tribunais, para seus nacionais, é em princípio, indiferente apurar se o divórcio "ali é litigioso e por que causas, se por mútuo consentimento e em que forma e condições, ou se, qual na espécie, pela simples vontade de um dos cônjuges".

Atualmente, porém, o repúdio é uma instituição em declínio. Alguns países do mundo muçulmano vêm abrandando os abusos do "talak", só reconhecendo efeitos legais, quando tenha sido proferido perante um Juiz, religioso ou civil.

Em sua obra "A Nova Lei do Divórcio Comentada", Domingos Sávio Brandão Lima assevera:

“A Argélia, Jordânia, Irã, Iraque, Paquistão, Marrocos e Síria, em legislação recente, procuraram coibir os abusos do repúdio e só reconhecem efeitos legais, quando tenha sido proferido perante um Juiz religioso ou civil, objetivando ainda tutelar os direitos da mulher" (A. cit., Ob. cit., p. 106).

Feitas estas considerações preliminares, verifica-se da documentação anexada o seguinte:

a) - o requerente, nos termos da Lei n. 1.961 , Legislação 
Muçulmana de Família, após o pronunciamento do "talak" requereu o divórcio em 31 de janeiro de 1972, tendo notificado ao Conselho de Arbitramento que, após envidar esforços para a reconciliação, dentro do prazo legal, o confirmou tornando-o irrevogável (fl. 16).

b) - por outro lado, o divórcio requerido, em 31 de janeiro de 1972, tendo em vista a expiração do prazo de 90 dias sem que houvesse a reconciliação, foi afinal decretado por sentença do Dr. Juiz de Direito da Corte Municipal de Karachi, em 21 de fevereiro de 1973, e de acordo com a Legislação Muçulmana da Família (1961), tornou-se efetivo. (fl. 24).

c) - embora não conste dos documentos anexados prova efetiva de que a requerente foi citada para responder aos termos do divórcio, pode-se depreender que tal ciência existiu, isto porque:

1) o Conselho de Arbitramento, composto de um presidente e de representantes de cada parte, envidou esforços no sentido de conciliar os cônjuges, não tendo obtido êxito; e

2) o cônjuge Shahnaz Mirza foi devidamente representada no processo de divórcio perante o Juízo Municipal, tendo afirmado a impossibilidade da conciliação;

3) de acordo com a Legislação Muçulmana de Família, o cônjuge Shahnaz Mirza recebeu cópia por escrito do "Talak" pronunciado pelo requerente.

d) toda a documentação trazida aos autos devidamente autenticada por S. Ex. ${ }^{a}$ o Embaixador do Paquistão no Brasil, cuja firma acha-se reconhecida por autoridade consular brasileira.

Ante o exposto, cumpridas a's formalidades legais, merece a presença sentença ser homologada sem quaisquer restrições.

Nestes termos e anexando cópia da Legislação Muçulmana de Família (1961).

Pede Juntada.

Brasília, 16 de agosto de 1978. Sérgio Gonzaga Dutra, Adv. inscr. 27 - $O A B$ - DF". 
3. A douta Procuradoria-Geral da República ouvida, afinal, assim se manifestou, fls. $56 / 57$ :

“1. Sente-se o Ministério Público no dever de ponderar que o parecer do douto curador à lide conta, na sua integralidade, com algum respaldo doutrinário. Mesmo a jurisprudência dessa alta Corte já terá abonado um dia, como faz crer a citação de fls. 47/48, a homologabilidade do divórcio consumado mediante repúdio.

2. A Procuradoria-Geral mantém, todavia, o ponto de vista expresso nos autos de S. E. 2.373, julgada pelo Tribunal Pleno em 10 de novembro de 1977.

3. Não obstante, no caso sob exame se encontra retratado um divórcio que a Justiça do Paquistão decretou ao cabo de processo em si mesmo inócuo à ordem pública brasileira. As partes, ambas presentes ao feito, e ali, sem discriminação, habilitadas a arrazoar, fizeram objeto até mesmo de uma injunção conciliatória por parte da corte. Bem diverso é o quadro que aqui se nos apresenta daquele estampado na S. E. 2.373, originária do Egito, e onde vinha à luz um divórcio decretado após a só e exclusiva manifestação de vontade do varão.

4. Assim, fiel embora à tese expressa nos autos daquele precedente, não vê a Procuradoria-Geral presentes, na espécie, seus pressupostos de fato, e por isso, subscrevendo as conclusões do douto curador, opina pelo deferimento do pedido.

Brasília, 22 de setembro de 1978. - José Francisco Rezek, Procurador da República.

Aprovo: (a) Henrique Fonseca de Araújo, Procurador da República".

Isto posto, homologo a referida sentença de divórcio, nos termos dos pareceres transcritos.

Publique-se.

Brasília, DF, em 5 de outubro de 1978. Carlos Thompson Flores, Presidente. (in Supremo Tribunal Federal, Sentenças Estrangeiras, 1979, ps. 649/652). 